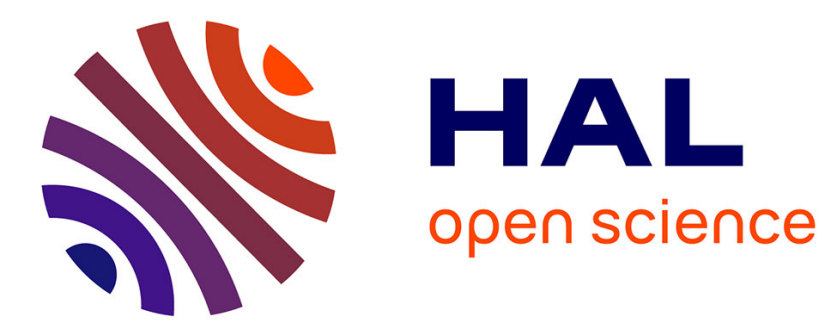

\title{
Diurnal variation of nitric oxide in the upper stratosphere
}

\author{
Y. Kondo, P Aimedmu, Michel Pirre, W. A Matthews, R. Ramaroson, W. \\ Sheldon, J.L. Benbrook, A. Iwata
}

\section{- To cite this version:}

Y. Kondo, P Aimedmu, Michel Pirre, W. A Matthews, R. Ramaroson, et al.. Diurnal variation of nitric oxide in the upper stratosphere. Journal of Geophysical Research, 1990, 95 (D13), pp.22513. 10.1029/JD095iD13p22513 . insu-02796542

\section{HAL Id: insu-02796542 https://hal-insu.archives-ouvertes.fr/insu-02796542}

Submitted on 5 Jun 2020

HAL is a multi-disciplinary open access archive for the deposit and dissemination of scientific research documents, whether they are published or not. The documents may come from teaching and research institutions in France or abroad, or from public or private research centers.
L'archive ouverte pluridisciplinaire HAL, est destinée au dépôt et à la diffusion de documents scientifiques de niveau recherche, publiés ou non, émanant des établissements d'enseignement et de recherche français ou étrangers, des laboratoires publics ou privés. 


\title{
Diurnal Variation of Nitric Oxide in the Upper Stratosphere
}

\author{
Y. Kondo, ${ }^{1}$ P. Aimedieu, ${ }^{2}$ M. Pirre, ${ }^{3}$ W. A. Matthews, ${ }^{4}$ R. Ramaroson, ${ }^{3}$ \\ W. R. Sheldon, ${ }^{5}$ J. R. BenBrook, ${ }^{5}$ and A. Iwata ${ }^{1}$
}

\begin{abstract}
Two recent measurements of the temporal variation of nitric oxide at constant altitude near $40 \mathrm{~km}$ are reported. The observations were made at float altitude with a balloon-borne chemiluminescence detector together with in situ ozone measurements. The first measurement was made at $44^{\circ} \mathrm{N}$ on September 17, 1987, at an altitude of $40 \mathrm{~km}$ from before sunrise until 1000 LT. The second observation was made at the same latitude on June 18,1988 at $39 \mathrm{~km}$ from 0800 to 1230 LT. The precision of the NO measurements is about $10 \%$ at these altitudes, obtained through a more accurate determination of the sample flow rate at pressures down to $2 \mathrm{mbar}$ with a reduced ozone/oxygen flow rate. At an altitude of $\mathbf{4 0} \mathrm{km}$, nitric oxide was observed to start increasing very rapidly at Bunrise when the solar zenith angle reached about $95^{\circ}$. After the rapid initial buildup, the rate of NO increase stabilized for 3 hours at about $1.2 \mathrm{ppbv} / \mathrm{hour}$. Near $1100 \mathrm{LT}$ at $39 \mathrm{~km}$ in summer the NO mixing ratio was observed to become nearly constant. These features of the diurnal variation of NO are in accord with the temporal variation expected from a time-dependent zero-dimensional photochemical model. Mixing ratios of $\mathrm{NO}_{y}$ and $\mathrm{N}_{2} \mathrm{O}_{5}$ have been determined from the measured temporal variation of $\mathrm{NO}$ at $39.5 \pm 0.5 \mathrm{~km}$, using the photochemical model of Pirre et al. (1989). These derived values of the $\mathrm{NO}_{y}$ and $\mathrm{N}_{2} \mathrm{O}_{5}$ mixing ratios, $15.5 \pm 5.0 \mathrm{ppbv}$ and $1.4 \pm 0.6 \mathrm{ppbv}$, respectively, are in good agreement with other recent measurements by balloon-borne and space-borne infrared experiments.
\end{abstract}

\section{INTRODUCTION}

The catalytic reaction cycle of atomic oxygen and osone with nitric oxide (NO) and nitrogen dioxide $\left(\mathrm{NO}_{2}\right)$ is estimated to be the major loss process for ozone throughout the stratosphere below about $40 \mathrm{~km}$ [e.g., McElroy and Salawitch, 1989]. In addition, these oxides of nitrogen $\left(\mathrm{NO}_{\infty}\right)$ interact with reactive chlorine species in the following way: NO reacts with $\mathrm{ClO}$ through the reaction

$$
\mathrm{ClO}+\mathrm{NO} \rightarrow \mathrm{Cl}+\mathrm{NO}_{2}
$$

which competes with the reaction

$$
\mathrm{ClO}+\mathrm{O} \rightarrow \mathrm{Cl}+\mathrm{O}_{2}
$$

Reaction (R2), together with reaction

$$
\mathrm{Cl}+\mathrm{O}_{3} \rightarrow \mathrm{ClO}+\mathrm{O}_{2}
$$

completes the well-known catalytic cycle of ozone destruction. The role of reaction (R1) is pronounced in the upper stratosphere, where NO is relatively abundant. In the lower stratosphere, reaction

$$
\mathrm{NO}_{2}+\mathrm{ClO}+\mathrm{M} \rightarrow \mathrm{ClONO}_{2}+\mathrm{M}
$$
Japan.

${ }^{1}$ Solar-Terrestrial Environment Laboratory, Nagoya University,

${ }^{2}$ Service d'Aéronomie, Centre National de la Recherche Scientifique, France.

${ }^{3}$ Laboratoire de Physique et Chimie de l'Environnement, CentreNational de la Recherche Scientifique, Orléans, France.

${ }^{4}$ Department of Scientific and Industrial Research, Physical Sciences, New Zealand.

${ }^{5}$ Department of Physics, University of Houston, TX.

Copyright 1990 by the Americen Geophysical Union.

Paper number 90JD01981.

0148-0227/90/90JD-01981\$05.00 becomes important in temporarily sequestering both $\mathrm{ClO}_{\text {s }}$ and NO. Since there is interaction between reactive species of chlorine and nitrogen, it is predicted that the rate of ozone destruction by an increase in stratospheric chlorine depends critically on the $\mathrm{NO}_{\text {s }}$ or $\mathrm{NO}_{y}$ concentration [e.g., Isaksen and Stordal, 1986].

In the daytime upper stratosphere, nitric oxide (NO) becomes the most abundant species of total reactive nitrogen, defined as $\mathrm{NO}_{4}=\mathrm{NO}+\mathrm{NO}_{2}+\mathrm{NO}_{3}+2\left(\mathrm{~N}_{2} \mathrm{O}_{5}\right)+\mathrm{HNO}_{3}$ $+\mathrm{HNO}_{4}+\mathrm{ClONO}_{2}$. The concentration of $\mathrm{NO}$ is controlled by the $\mathrm{NO}_{y}$ concentration and the photochemical partitioning among the $\mathrm{NO}_{y}$ species. The dominance of $\mathrm{NO}$ in the $\mathrm{NO}_{y}$ family during the daytime is discussed later when the measurements are compared to the model calculations of Pirre et al. [1989]. Since $\mathrm{NO}_{y}$ has a photochemical time constant of about a month in the upper stratosphere [Shimazaki, 1984], it is constant on the time scale of a day in the same air mass. Consequently, the diurnal variation of NO is caused by change in the $\mathrm{NO} / \mathrm{NO}_{y}$ ratio which results from photodissociation of reservoir species such as $\mathrm{N}_{2} \mathrm{O}_{3}$ and $\mathrm{ClONO}_{2}$, and by variation in the $\mathrm{NO} / \mathrm{NO}_{2}$ ratio. In order to investigate the complex chemistry of odd nitrogen in the stratosphere under changing conditions of solar illumination, precise measurements of the diurnal variation of $N O$ in the same air mass are needed.

Observations of the diurnal variation of $N O$ in the upper stratosphere are very limited; however, at lower altitudes, more observations have been made, mainly with in situ chemiluminescence NO detectors [e.g., Ridley et al., 1977; Kondo et al., 1985, 1988, $1989 a, b]$ (see Kondo et al., [1988] for a more complete set of references). Ridley and Schiff [1981] measured the temporal variation of $\mathrm{NO}$ at $\mathbf{4 0} \mathrm{km}$ near sunset. Roscoe et al. [1986] observed the temporal variation of NO between 32 and $43 \mathrm{~km}$ in the morning hours, as well as in the afternoon, using a balloon-borne infrared emission radiometer. To investigate the photochemistry of odd nitrogen, precise measurements of NO in the morning are very important because photodissociation of the various reservoir species, such as $\mathrm{N}_{2} \mathrm{O}_{5}$, occurs at that time.

The NO measurements reported here are more accurate than previous determinations using the chemiluminescent technique. 
We have significantly improved the precision of chemiluminescent NO measurements, mainly through a more precise determination of the flow rates relevant to our balloon-borne chemiluminescence detector [Kondo et al, 1989c]. Here the diurnal variation of $\mathrm{NO}$ at about $\mathbf{4 0} \mathrm{km}$ from sunrise through midafternoon is reported. Quantitative comparison of the observed results with a photochemical model is described. A detailed analysis of the observed and calculated diurnal NO variation allowed estimates to be made of the $\mathrm{NO}_{y}$ and $\mathrm{N}_{2} \mathrm{O}_{5}$ mixing ratios.

\section{INSTRUMENTATION}

The two balloon measurements of NO presented here were made in 1987 and 1988 with a chemiluminescence detector. This instrument was used previously for balloon observations up to $32 \mathrm{~km}$ in 1983 and 1985 [Kondo et al., 1985, 1988]; after those experiments the instrument was modified to achieve better precision at $40 \mathrm{~km}$. Detailed descriptions of the chemiluminescence NO detector used for the present experiments have been presented by Kondo et al. [1989a, b, c]. Fluctuations of the gero level of the instrument have been used to obtain an estimate of 25 pptv as the detection limit of the NO instrument for $10 \mathrm{~s}$ of operation. This value was confirmed during the nighttime flight in 1987 , as described later. For NO mixing ratios above the detection limit the major sources of error in the NO measurements are the uncertainty in the mixing ratio of $\mathrm{NO}$ in the $\mathrm{N}_{2}$ gas used for calibration during flight, and the mass flow rates of the NO calibration gas and of the sample air. The fluctuation level of the signal is not significant during daytime NO measurements. One of our gas bottles with an NO concentration of 1.98 ppmv used for calibration has been evaluated recently at the NOAA Aeronomy Laboratory where this value was confirmed within an accuracy of $3 \%$ (D. W. Fahey, private communication, 1990). Estimates of the uncertainties in the NO measurements are given in Table 1. The precision of the NO measurement derived by adding these uncertainties is about $10 \%$. For the second balloon experiment in 1988 the NO instrument was further modified to measure $\mathrm{NO}_{y}$ by adding a gold converter [Kondo et al., 1990]. A schematic diagram of the $\mathrm{NO} / \mathrm{NO}_{y}$ instrument is shown in Figure 1. The sample air is drawn through the inlet by a Roots pump directly to the reaction chamber for NO measurements. In an alternative measurement mode, sample air first passes through a gold converter heated to $300^{\circ} \mathrm{C}$ to reduce $\mathrm{NO}_{y}$ into NO catalytically, upstream of the reaction chamber. In order to maintain a high conversion efficiency of $\mathrm{NO}_{y}$ to $\mathrm{NO}$, purified carbon monoxide (CO), passed through charcoal and Teflon filters, is mixed with

TABLE 1. Uncertainties in $\mathrm{NO}$ and $\mathrm{NO}_{y}$ Measurements

\begin{tabular}{lcc}
\hline Parameter & \multicolumn{2}{c}{ Uncertainty \% } \\
\cline { 2 - 3 } & $\mathrm{NO}$ & $\mathrm{NO}_{y}$ \\
\hline Zero level & $<0.1$ & $5^{*}$ \\
Mixing ratio of & & \\
$\quad$ NO cal gas & 3 & 3 \\
Cal gas flow rate & 2 & 2 \\
Sample air flow rate & $5^{\dagger}$ & $20^{*}$ \\
Conversion efficiency & $\ldots$ & 2 \\
Fluctuation of signal & $1^{\dagger}$ & $3^{*}$ \\
\hline
\end{tabular}

$\dagger_{\text {Values for }} \mathbf{4 0 - k m}$ altitude.

*Values for 28-km altitude. the sample air [Bollinger et al., 1983; Fahey et al., 1985]. The efficiency of conversion of $\mathrm{NO}_{2}$ into $\mathrm{NO}$ has been measured in the laboratory to be $0.99 \pm 0.02$ at pressures between 7 and 60 mbar [Kondo et al, 1990]. The sensitivity of the $\mathrm{NO}_{y}$ system for NO is calibrated during the flight periodically in the same way as for the NO measurement. The sero level of the $\mathrm{NO}_{\mathrm{y}}$ system is determined by adding compressed purified air near the entrance of the inlet tube. The $\mathrm{NO}_{\mathbf{y}}$ measurement system of this $\mathrm{NO} / \mathrm{NO}_{\mathrm{y}}$ instrument is described in detail by Kondo et al. [1990]. The instrument used in the 1988 flight can be switched by telecommand from the $\mathrm{NO}$ to the $\mathrm{NO}_{y}$ measurement mode and vice versa during a flight. In 1988 it was operated in the $\mathrm{NO}_{y}$ mode during ascent between 12 and $28 \mathrm{~km}$ and in the NO mode afterward. The sources of errors that affect the precision of the $\mathrm{NO}_{y}$ measurements and their estimated values are listed in Table 1. The uncertainty of the flow rate of the sample air for $\mathrm{NO}_{y}$ measurements is significantly larger than that for NO measurements, due to a much reduced flow rate through the converter, especially at pressures lower than 30 mbar. By surming these uncertainties the precision of $\mathrm{NO}_{\mathrm{y}}$ measurement is estimated to be $35 \%$ at $28 \mathrm{~km}$ and $25 \%$ at 20 km. In both flights, ozone was measured in situ on board the gondola with a UV photometer from the University of Houston [Robbins, 1985; Robbins et al., 1990] to an accuracy of about $\pm 5 \%$ and with a chemiluminescent ozone instrument from Service d'Aéronomie [Aimedieu and Barat, 1981; Aimedieu, 1983; Aimedieu et al., 1987] to an accuracy of about $\pm 10 \%$.

\section{Balloon Observations}

The first of these observations in the upper stratosphere was made on September 17, 1987, on a balloon launched from the Centre National d'Etudes Spatiales (CNES) balloon-launching center at Aire sur l'Adour in France $\left(44^{\circ} \mathrm{N}, 0^{\circ} \mathrm{W}\right)$. The gondola was suspended $250 \mathrm{~m}$ below a $600,000-\mathrm{m}^{3}$ balloon; launch was at 0210 universal time (UT), and float altitude of $40.2 \mathrm{~km}$ (2.7 mbar) was reached at around 0500 UT. Measurements of NO at this altitude were made until around $1000 \mathrm{UT}$, at which time a slow descent was initiated. The NO profile obtained during the descent has been presented by Kondo et al. [1989a], together with the temperature profile and the ozone profile measured by the UV photometer. The ozone mixing ratio measured at float altitude by the UV photometer and the chemiluminescence instrument were 5.8 and $5.7 \mathrm{ppmv}$, respectively; the temperature at float altitude was $-27^{\circ} \mathrm{C}$. A photograph taken from Meteosat II at 0930 UT shows that southern France was dotted with a light cloud cover of a few percent at that time.

The measured NO concentration versus UT at float altitude is shown in Figure 2, along with fluctuations in the altitude of the balloon. During this flight, local solar time and UT were nearly identical; local solar time was only $1.5 \mathrm{~min}$ ahead of $\mathrm{UT}$ at sunrise. The variation of the NO concentration near sunrise is shown in greater detail in Figure 3 as a function of solar zenith angle (SZA). The nighttime value of the NO mixing ratio was about $0 \pm 0.02$ ppbv. At sunrise, when the SZA decreased to $96^{\circ}$, NO started to increase slightly and then increased rapidly between $95^{\circ}$ and $91^{\circ}$. For reference, a calculated curve of the $\mathrm{NO}_{2}$ photodissociation coefficient $\left(J_{N O 2}\right)$, as described below, is also shown in this figure; the simultaneous increases in the measured NO mixing ratio and $J_{N O 2}$ near sunrise can be noted. After $0600 \mathrm{UT}$, NO continued to increase at an average rate of $1.2 \mathrm{ppbv} /$ hour for three hours. Kondo et al. $[1988,1989 b]$ observed a similar increase in NO at 33 and 26 


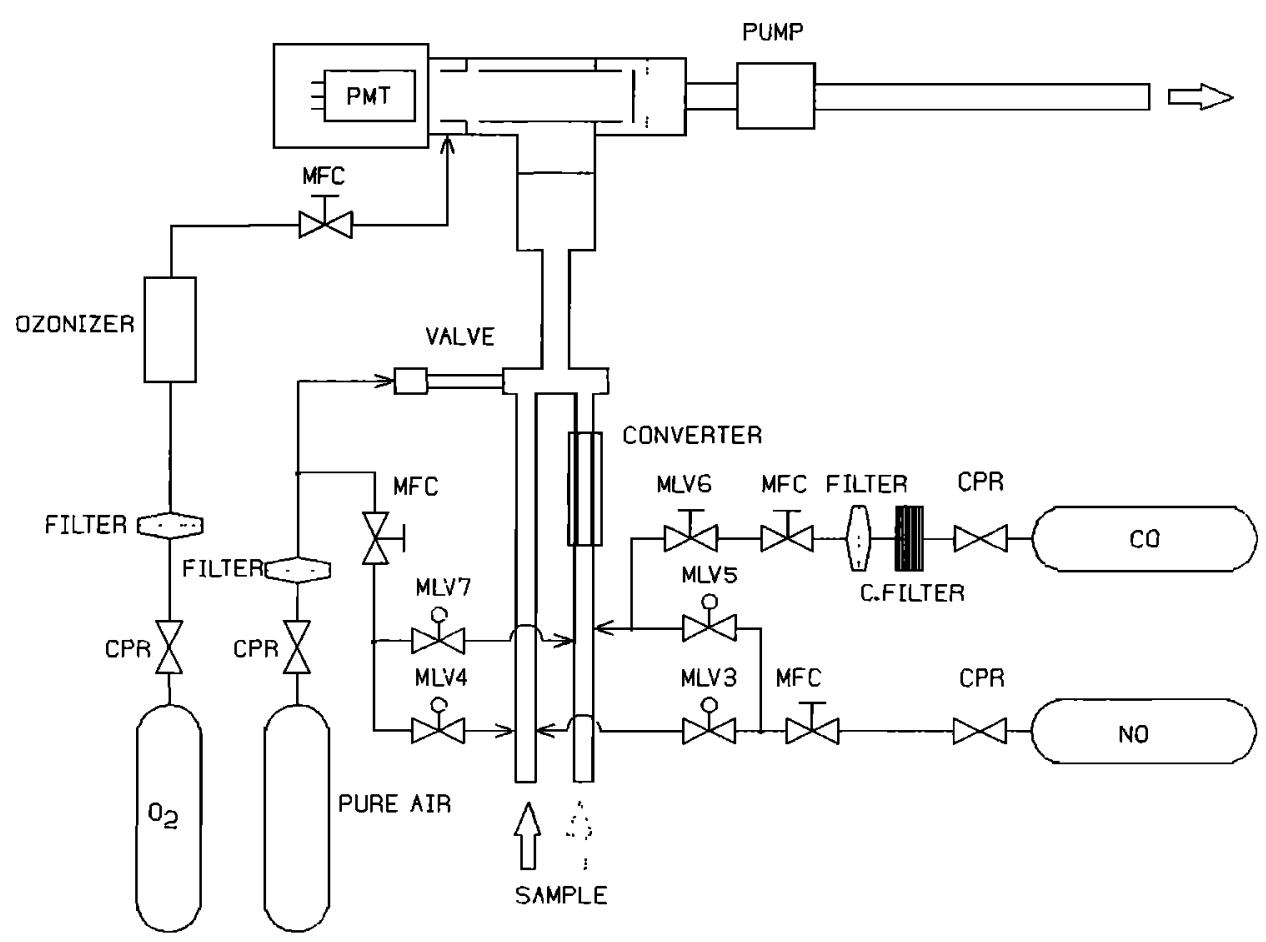

Fig. 1. Schematic diagram of the $\mathrm{NO} / \mathrm{NO}_{y}$ instrument used for the flight on June 18, 1988. MLV, magnetic latch valve; MFC, mass flow controller; CPR, constant pressure regu- lator; PMT, photomultiplier tube; and C. Filter, charcoal filter.

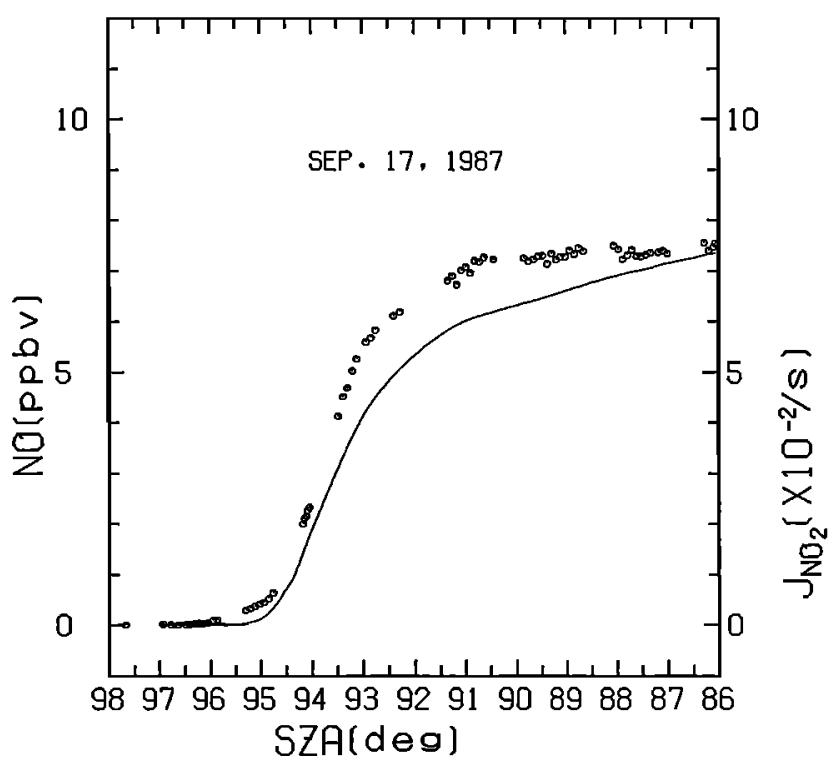

Fig. 3. Temporal variation of NO near sunrise versus SZA. The calculated photodissociation coefficient of $\mathrm{NO}_{2}$ provided by S. Solomon (private communication, 1990) is shown as a solid line.

variation of NO in the late morning hours, was launched on June 18, 1988, from the CNES balloon launching site at Gap $\left(44.5^{\circ} \mathrm{N}, 6^{\circ} \mathrm{E}\right)$ using a $400,000-\mathrm{m}^{3}$ balloon. The same gondola, but with the $\mathrm{NO} / \mathrm{NO}_{\mathrm{y}}$ instrument for this flight, was launched

at $0503 \mathrm{UT}$ and reached a float altitude of $39.1 \mathrm{~km}(3.7 \mathrm{mbar})$ $\mathrm{km}$. The rate of increase in NO seems to have become smaller around 0930 UT. However, there are irregular variations in the NO data, so the detailed structure of the diurnal variation of NO in the late morning is not well defined by the present data.

The second experiment, which investigated the temporal

\section{完}

Fig. 2. Temporal variation of NO versus nniversal time (UT) balloon is shown as a solid line. Solar zenith angle (SZA) is given on the upper scale. 
at 0735 UT. It stayed at that altitude until a slow descent was initiated at around 1200 UT. The descent NO profile between 39 and $28 \mathrm{~km}$ measured in the afternoon has been presented by Kondo et al. [1989a], together with the osone and temperature profiles. The $\mathrm{NO}_{\mathrm{y}}$ measurements performed during the ascent at altitudes between 12 and $28 \mathrm{~km}$ have also been described previously [Kondo et al., 1990]. The temperature and ozone mixing ratio measured by the UV photometer at float altitude were $-14^{\circ} \mathrm{C}$ and $5.3 \pm 0.2 \mathrm{ppmv}$, respectively. From a photograph taken by Meteosat II at 1200 UT, about $20 \%$ of southern France was covered with clonds. However, the region below the balloon flight path was free of thick clouds.

The NO mixing ratio measured at float altitude from 0730 until $1230 \mathrm{UT}$ is shown in Figure 4. Local time was $16 \pm 7 \mathrm{~min}$ in advance of UT during this flight. During the first half of this period the NO concentration increased slowly from about 11 to $12 \mathrm{ppbv}$, after which time it became nearly constant. By combining the data from the two flights reported here, the diurnal variation of NO near $40 \mathrm{~km}$ from before sunrise until past local noon has been experimentally measured.

\section{Results and Discussion}

For quantitative analysis of the observed NO data, a timedependent zero-dimensional model described by Pirre et al. [1989] was used. Related reaction rate coefficients appropriate for the measured temperatures were adopted from Jet Propulsion Laboratory [1987] (hereinafter JPL [1987]). From the mixing ratio of total reactive nitrogen $\left(\left[\mathrm{NO}_{y}\right]=[\mathrm{NO}]+\left[\mathrm{NO}_{2}\right]+\right.$ $\left.\left[\mathrm{NO}_{3}\right]+2\left[\mathrm{~N}_{2} \mathrm{O}_{5}\right]+\left[\mathrm{HNO}_{3}\right]+\left[\mathrm{HO}_{2} \mathrm{NO}_{2}\right]+\left[\mathrm{ClONO}_{2}\right]\right)$ at 40 and $39 \mathrm{~km}$ and the diurnal variation of the SZA, the temporal variation of each species can be calculated. For the partitioning between $\mathrm{NO}$ and $\mathrm{NO}_{2}$ the photodissociation of $\mathrm{NO}_{2}$ plays an important role. The $\mathrm{NO}_{2}$ photodissociation coefficient, $J_{N O 2}$, has been calculated recently by Solomon et al. [1989]; here, values of $J_{\mathrm{NO}}$ provided by $S$. Solomon (private communication, 1990) have been used for SZA larger than $85^{\circ}$ and are shown in Figure 3. The effects of multiple scattering were included in the calculation, and an albedo of 0.15 was assumed, consistent with the light cloud cover observed during both balloon flights. All other calculated results described in this paper are based on the model of Pirre et al. [1989].

\section{NO Diurnal Variation}

First, the temporal variation of NO has been calculated for the conditions at float altitude on September 17. The measured temperature of $-27^{\circ} \mathrm{C}$ and an ozone mixing ratio of 5.75 ppmv (the average of the values measured by the two ozone instruments) were used at the pressure level of 2.80 mbar for the calculation. The calculated temporal variation of NO for three values of the $\mathrm{NO}_{\mathrm{y}}$ mixing ratio $(14.0,14.5$, and $15.0 \mathrm{ppbv})$ are compared with the observed values in Figure 5 . The calculated NO concentration agrees with that observed to within $0.5 \mathrm{ppbv}$, or $5 \%$. This agreement is quite good considering the accuracy of the measurements and the fuctuation in the data. But when the comparison is examined in more detail, it is noted that the observed rate of the increase in NO between 0530 and 0700 IT exceeds the calculated rate. However, in Figure 5 it can be seen that (1) the calculated initial buildup of NO at sunrise is the same for all three valnes of $\mathrm{NO}_{y}$, (2) the final phase of the initial increase agrees best with an $\mathrm{NO}_{\mathrm{y}}$ concentration of $14.0 \mathrm{ppbv}$, and (3) the measured late moming NO concentration agrees best with $\mathrm{NO}_{\mathrm{y}}=15.0 \mathrm{ppbv}$.

To compare in detail the first hour of increase in NO at the beginning of the morning, the calculeted values of NO for

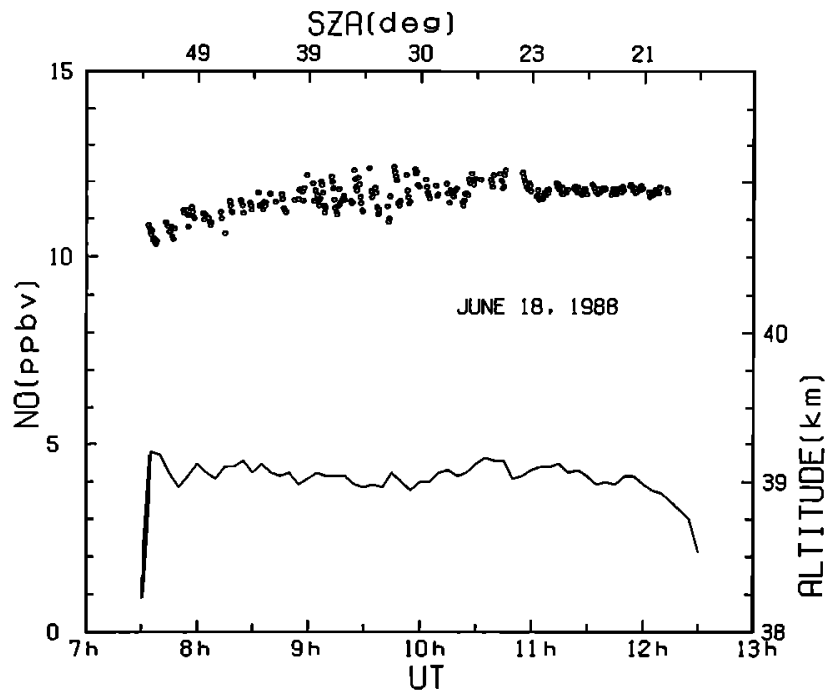

Fig. 4. The same as Figure 2, but for the observation at 39 km on June 18, 1988.

$\left[\mathrm{NO}_{\mathrm{y}}\right]=14.5 \mathrm{ppbv}$ were compared with the observations as a function of solar senith angle, as shown in Figure 6 . In this figure it can be seen that agreement between the observed and calculated NO mixing ratio is noticeably improved by assuming

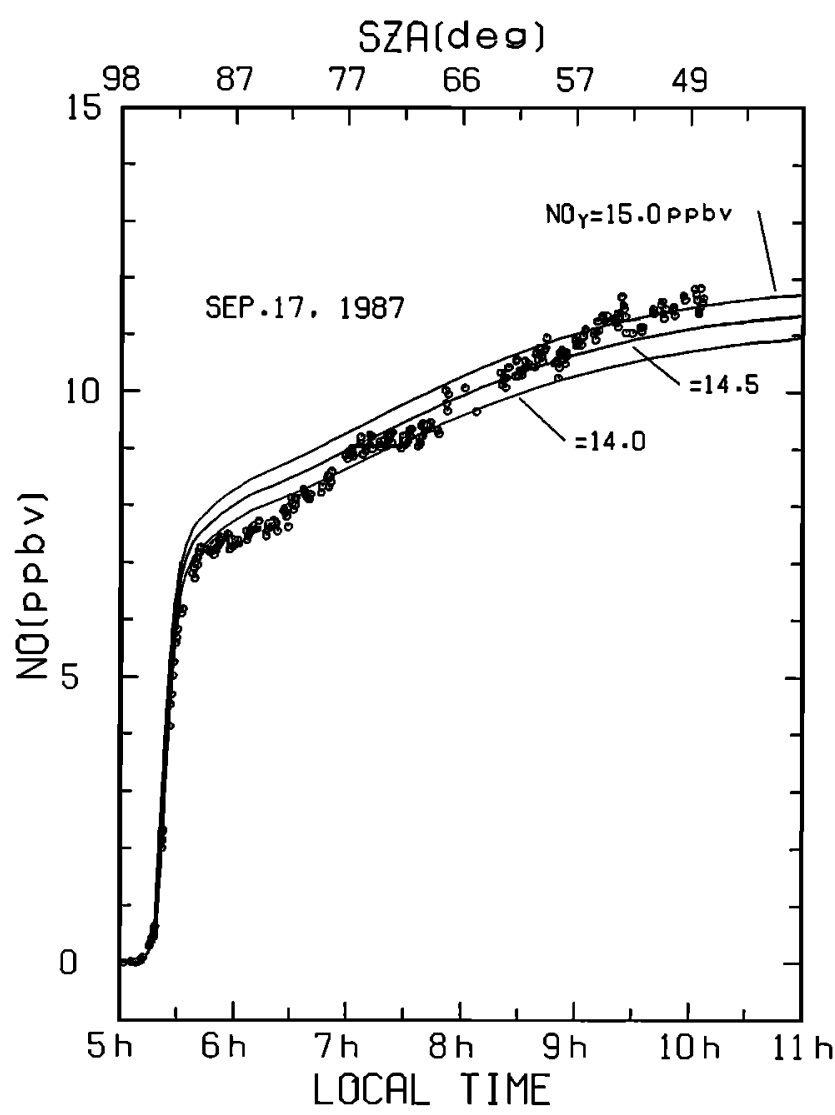

Fig. 5. Comparison of measured (circles) and computed valnes (solid lines) of the NO mixing ratio versus local time (LT) for the observations of September 17, 1987. Computed curves are for $\mathrm{NO}_{y}$ values of $14.0 \mathrm{ppbv}$ (bottom curve), 14.5 ppbv (middle curve), and 15.0 ppbr (top curve). 


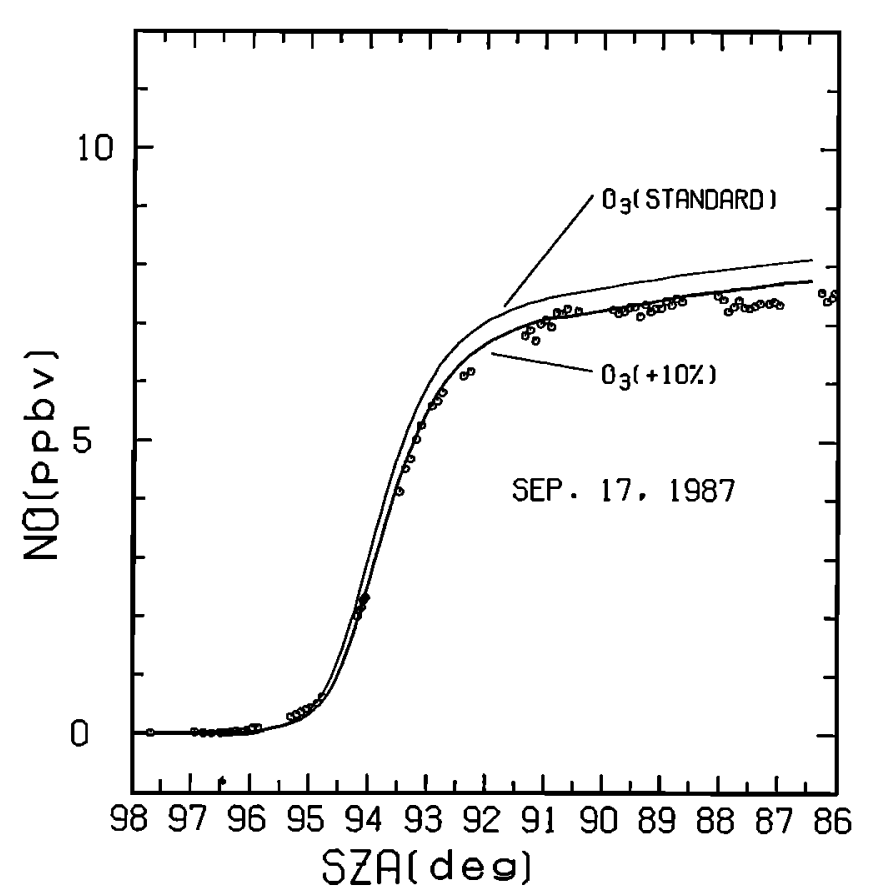

Fig. 6. Comparison of measured values (circles) and computed curves (solid line) of the NO mixing ratio near sunrise on September 17, 1987, for SZA less than $86^{\circ}$. For the calculation, an $\mathrm{NO}_{y}$ mixing ratio of $14.5 \mathrm{ppbv}$ was assumed. The thin curve resulted from using the ozone concentration measured just before sunrise, and the thick curve resulted in an assumed average increase of $10 \%$ in the orone concentration or the equivalent through an increase in $k_{5}$ (see text).

an ozone concentration during the previous night $10 \%$ larger than that measured just before sunrise. The change in NO during this phase is due mostly to the photodissociation of $\mathrm{NO}_{2}$, as investigated in more detail below using the numerical model. There is remarkable agreement between observed and calculated values of NO during the rapid increase at SZAs between $95^{\circ}$ and $92^{\circ}$.

Since an assumed increase in the ozone concentration resulted in improved agreement in Figure 6, the effect of ozone on the form of the diurnal variation of $N O$ is discussed below. The rate of increase in NO during the first few hours after sunrise depends significantly on the amonnt of $\mathrm{N}_{2} \mathrm{O}_{3}$ present at that time. An augmented amount of $\mathrm{N}_{2} \mathrm{O}_{5}$ would increase the rate at which NO builds ap just after sunrise due to a reduced NO. concentration and a larger production rate of $\mathrm{NO}_{0}$ through the photodissociation of $\mathrm{N}_{2} \mathrm{O}_{5} . \mathrm{N}_{2} \mathrm{O}_{5}$ is formed during the night by reactions

$$
\begin{gathered}
\mathrm{NO}_{2}+\mathrm{O}_{3} \rightarrow \mathrm{NO}_{3}+\mathrm{O}_{2} \\
\mathrm{NO}_{2}+\mathrm{NO}_{3}+\mathrm{M} \rightarrow \mathrm{N}_{2} \mathrm{O}_{5}+\mathrm{M}
\end{gathered}
$$

The rate coefficient $k_{\mathrm{b}}$ is

$$
k_{5}=1.4 \times 10^{-13} \exp (-2500 / T) \mathrm{cm}^{3} \mathrm{~s}^{-1}
$$

where $T$ is the temperature $\left({ }^{\circ} \mathrm{K}\right)[J P L, 1987]$.

The sum of the $\mathrm{NO}_{3}$ and $\mathrm{N}_{2} \mathrm{O}_{5}$ concentrations during nighttime is governed by the following continuity equation [Flaud et al., 1983]:

$$
\frac{d}{d t}\left(\left[\mathrm{NO}_{3}\right]+\left[\mathrm{N}_{2} \mathrm{O}_{5}\right]\right)=k_{5}\left[\mathrm{NO}_{2}\right]\left[\mathrm{O}_{3}\right]
$$

Consequently, the product $k_{5}\left[O_{3}\right]$ is expected to influence the diurnal variation after surrise. Also it should be noted that the values of $k_{B}$ and ozone concentration that control the nighttime production rate of $\mathrm{N}_{2} \mathrm{O}_{5}$ are not those that were measured during the early morning, but rather the values that prevailed from sunset on the previous day until sunrise. The uncertainties of the ozone mixing ratio and $k_{5}$ are summarized in Table 2. The temperature measurement at float altitude has an uncertainty of $2^{\circ} \mathrm{K}$. The uncertainties of the temperature of $1^{\circ}$ and $2^{\circ} \mathrm{K}$ are reflected in the 4 and $9 \%$ uncertainties in $k_{5}$. In addition, the uncertainty in the laboratory determination of $k_{5}$ is $25 \%$ for a temperature of $250^{\circ} \mathrm{K}$ [ $J P L, 1987$ ]. The effect of the change in osone on the diurnal variation of NO has been calculated and is shown in Figure 7 a. Improvement in the agreement between measured and calculated values of the NO concentration brought about by a $10 \%$ increase in the $\mathrm{O}_{3}$ mixing ratio is seen mainly in the region of SZAs greater than $86^{\circ}$. The calculated diurnal variation of NO by using $k_{B}$

TABLE 2. Uncertainties in $k_{5}\left[\mathrm{O}_{3}\right]$

\begin{tabular}{lc}
\hline & Uncertainty \% \\
\hline$\left[\mathrm{O}_{3}\right]$ & 10 \\
$k_{5}\left(\Delta T=1^{\circ} \mathrm{K}\right)$ & 4 \\
$k_{5}\left(\Delta T=2^{\circ} \mathrm{K}\right)$ & 9 \\
$k_{B}($ absolute $)$ & 25 \\
\hline
\end{tabular}

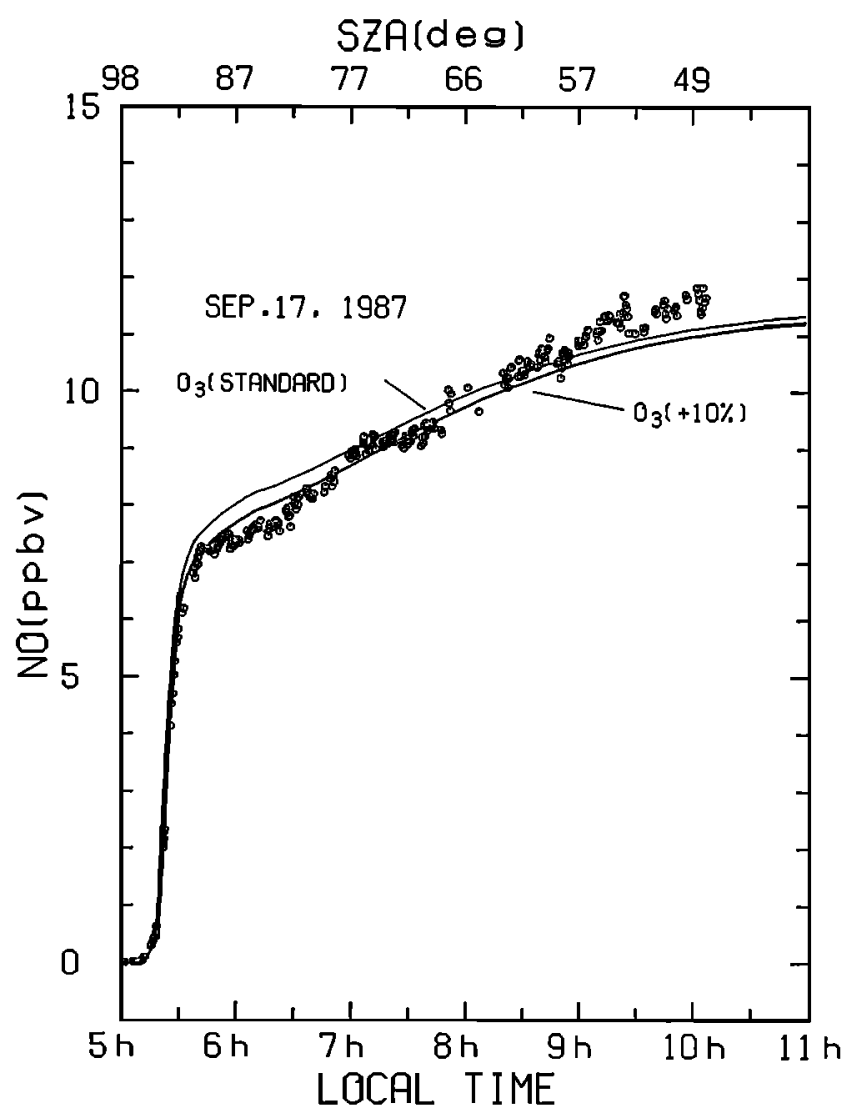

Fig. 7a. The same as Figure 6 but for all of the NO observations made at float altitude on September 17, 1987. 
increased by $25 \%$ is shown in Figare $7 b$. In this calculation the $\mathrm{NO}_{y}$ mixing ratio was assumed to be $14.7 \mathrm{ppbv}$, the value which provides the best overall egreement between calculated and measured NO valnes. It can be seen that the agreement between the observed and modeled NO rariations becomes improved to some extent. Since an increase in osone concentration has similar effect to a corresponding increase in $k_{5}, a 10 \%$ increase in the ozone mixing ratio and $15 \%$ increase in $k_{5}$ will have an effect similar to a $25 \%$ increase in $k_{b}$ alone.

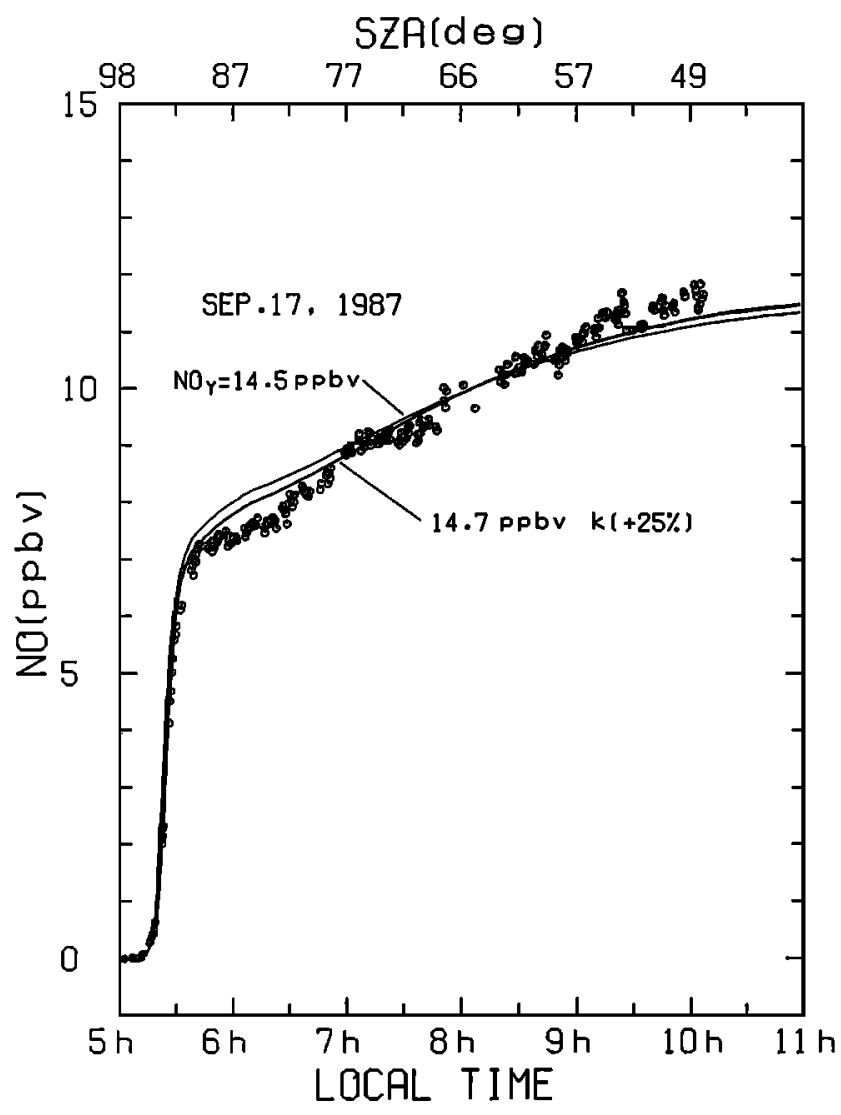

Fig. 7b. The same as Figure $7 a$ but for the computed curve (solid line); a value of $k_{5}$ increased by $25 \%$ was assumed. For this computation, an $\mathrm{NO}_{\mathrm{y}}$ mixing ratio of $14.7 \mathrm{ppbv}$ was assumed (see text). For comparison, the standard model result is also shown.

The change in albedo can affect the NO mixing ratio through the change in the photodissociation rate of $\mathrm{NO}_{2}$. It was found that adoption of an albedo as large as 0.6 increases the NO mixing ratio between 0900 and 1100 LT by about 0.5 ppbv or $5 \%$, while it causes little change in NO at hours earlier than $0730 \mathrm{LT}$. This effect increases the rate of change in NO and thus improves the agreement between the observation and the model. However, such a large albedo is quite unlikely on September 17 , when a very light cloud cover was observed, as already discussed.

In summary, it can be said that the observed and modeled diurnal variations agree to within the nncertainties in the measurements of NO, ozone, and temperature and the value of $k_{B}$.

Next, the temporal variation of NO observed at $39 \mathrm{~km}$ from 0800 LT to noon on Jnne 19, 1988, is compared with that calculated. The calculation was made for a pressure of 3.77 mbar, which was the mean float pressure level. The measured osone mixing ratio and the temperature at this altitude used in the calculation were $5.4 \mathrm{ppmv}$ and $-14^{\circ} \mathrm{C}$. The calculated results for $\left[\mathrm{NO}_{\mathrm{y}}\right]=16.0,16.5$, and $17.0 \mathrm{ppbv}$ are shown in Figure 8. It can be seen that the calculated curves agree with the observed NO concentration for $\left[\mathrm{NO}_{\mathrm{y}}\right]=16.5 \mathrm{ppbr}$ within $\dddot{ \pm 0.5} \mathrm{ppbv}$, a value within the uncertainty of the NO measurements. The calculation predicts an NO increase of about 1 ppbr between 0800 and $1200 \mathrm{LT}$, in good agreement with the observations.

The rate of NO increase after $0800 \mathrm{LT}$ and the daytime NO mixing ratio are insensitive to change in the ozone concentration of the order of $10 \%$, as can be seen from the calculated curves in Figure $7 a$. Therefore, for comparison of the calculated and observed NO concentration during late morning on June 18 the effect of the uncertainties discussed above for conditions at sunrise (September 17, 1987, observations) is negligible compared to the ancertainty in the NO measurements.

The calculated temporal variation of $\mathrm{NO}, \mathrm{NO}_{2}, \mathrm{NO}_{3}, \mathrm{NO}_{3}$ $=\mathrm{NO}+\mathrm{NO}_{2}+\mathrm{NO}_{3}, \mathrm{~N}_{2} \mathrm{O}_{5}$, and $\mathrm{HNO}_{3}$ species for $\left[\mathrm{NO}_{4}\right]=$ 16.5 ppbv at $39 \mathrm{~km}$ on June 18 are presented in Figure 9 to show the diurnal variation of the partitioning among the $\mathrm{NO}_{y}$ family. It can be seen that the change in NO during the first hour after sunrise is cansed mostly by the photodissociation of $\mathrm{NO}_{2}$, since the mixing ratio of $\mathrm{NO}_{2}$ (as defined just above) changes little during this period. It can also be seen that most of the photodissocietion of $\mathrm{N}_{2} \mathrm{O}_{3}$ occurs within 3 hours after sunrise. The rate of the increase in NO during this period is controlled by the rate of photodissociation of $\mathrm{N}_{2} \mathrm{O}_{3}$ and the slow shift in the $\mathrm{NO} / \mathrm{NO}_{2}$ ratio due to the incresse in $J_{\mathrm{NO2}}$

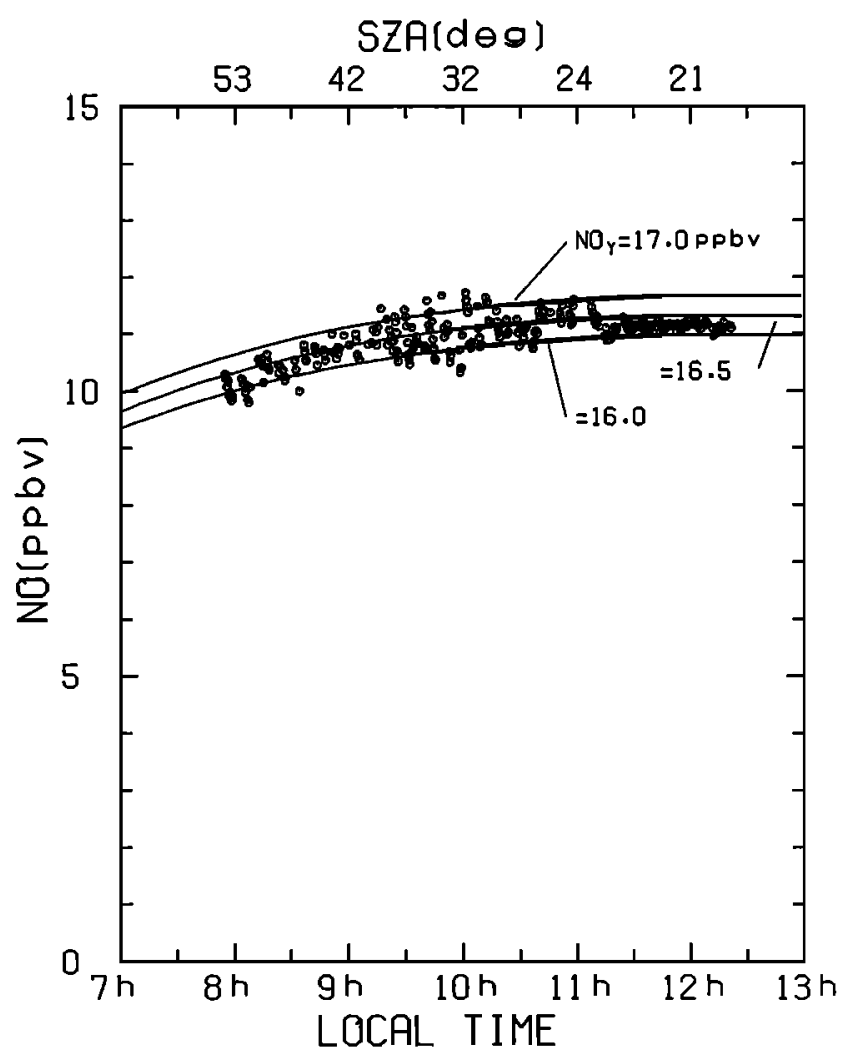

Fig. 8. Comparison of the measured (circles) and computed values (solid lines) of the NO mixing ratio for the observetions of June 18, 1988. Computed curves are for $\mathrm{NO}_{y}$ values of 16.0 ppbv (bottom curve), 16.5 ppbv (middle curve), and $17.0 \mathrm{ppbr}$ (top curve). 


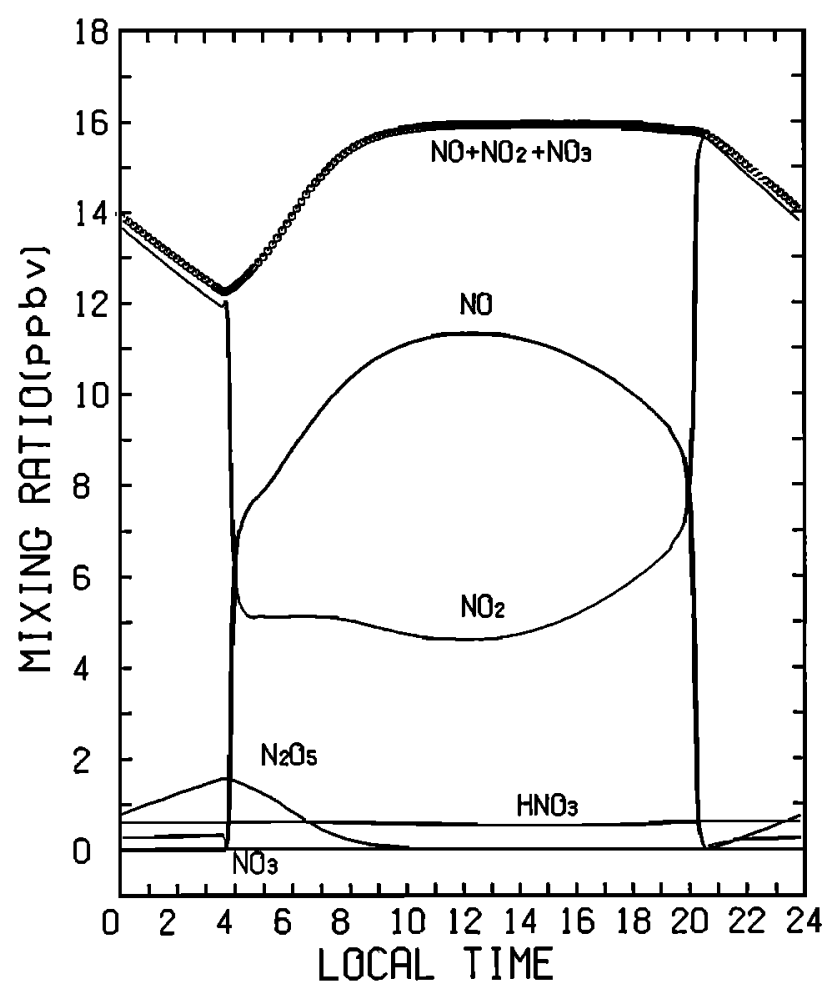

Fig. 9. Computed diurnal variation of $\mathrm{NO}, \mathrm{NO}_{2}, \mathrm{NO}_{3}, \mathrm{NO}_{2}$ $=\mathrm{NO}+\mathrm{NO}_{2}+\mathrm{NO}_{3}, \mathrm{~N}_{2} \mathrm{O}_{5}$, and $\mathrm{HNO}_{3}$ for an $\mathrm{NO}_{4}$ value of $16.5 \mathrm{ppbv}$ at $39 \mathrm{~km}$ on June 18 at $44^{\circ} \mathrm{N}$.

with decreasing SZA. The $\mathrm{HNO}_{3}$ concentration varies little, as can be seen from the figure, and the $\mathrm{ClONO}_{2}$ concentration is negligibly small at this altitude. This model shows that the daytime NO. concentration is very close to the total $\mathrm{NO}_{y}$ concentration and that daytime $\mathrm{NO}$ accounts for $70 \%$ of $\mathrm{NO}_{y}$.

$\mathrm{NO}_{y}$

As discussed above, the most probable values of the $\mathrm{NO}_{y}$ concentration at $40 \mathrm{~km}$ in September and $39 \mathrm{~km}$ in June are 14.5 ppbv and 16.5 ppbv, respectively. Previously, Kondo et al. [19896] reported an estimated $\mathrm{NO}_{y}$ concentration of 14 ppbv at $26 \mathrm{~km}$ at $32^{\circ} \mathrm{N}$ in July 1987 from a similar comparison of the observed and modeled diunal variation of NO. The $\mathrm{NO}_{y}$ concentration at $32.5 \mathrm{~km}$ can also be derived from the observed NO temporal variation at $44^{\circ} \mathrm{N}$ in October [Kondo et al., 1988]. However, their NO valnes at $32.5 \mathrm{~km}$ have been found to be overestimated by about $25 \%$ [Kondo et al, 19896]. These revised NO values and the present model yield a derived $\mathrm{NO}_{y}$ mixing ratio of $18.5 \mathrm{ppbr}$ at $32.5 \mathrm{~km}$. In estimating these values of the $\mathrm{NO}_{y}$ mixing ratio from the measured $\mathrm{NO}$ diurnal variation, uncertainties in the calculated [NO]/[NO $\left.{ }_{y}\right]$ ratio and in the measured $\mathrm{NO}$ mixing ratio contribute to the errors. The $[\mathrm{NO}] /\left[\mathrm{NO}_{\mathrm{v}}\right]$ ratio is expressed as

$$
\begin{gathered}
{[\mathrm{NO}] /\left[\mathrm{NO}_{\mathbf{y}}\right]=\left([\mathrm{NO}] /\left[\mathrm{NO}_{\mathbf{x}}\right]\right) \cdot\left(\left[\mathrm{NO}_{\mathbf{x}}\right] /\left[\mathrm{NO}_{\mathbf{y}}\right]\right)} \\
\left.=\left\{1 /\left(1+\left[\mathrm{NO}_{2}\right] /[\mathrm{NO}]\right)\right\} \cdot\left(\left[\mathrm{NO}_{\mathbf{x}}\right] / \mathrm{NO}_{\mathbf{y}}\right]\right)
\end{gathered}
$$

The $\left[\mathrm{NO}_{2}\right] /[\mathrm{NO}]$ ratio is governed by the following photochemical reactions:

$$
\overline{\mathrm{NO}}+\mathrm{O}_{3} \rightarrow \mathrm{NO}_{2}+\mathrm{O}_{2}
$$

$$
\begin{gathered}
\mathrm{NO}+\mathrm{ClO} \rightarrow \mathrm{NO}_{2}+\mathrm{Cl} \\
\mathrm{NO}+\mathrm{HO}_{2} \rightarrow \mathrm{NO}_{2}+\mathrm{OH} \\
\mathrm{NO}_{2}+h \nu \rightarrow \mathrm{NO}+\mathrm{O} \\
\mathrm{NO}_{2}+\mathrm{O} \rightarrow \mathrm{NO}+\mathrm{O}_{2}
\end{gathered}
$$

and is expressed as

$$
\left[\mathrm{NO}_{2}\right] /[\mathrm{NO}]=\left(k_{7}\left[\mathrm{O}_{3}\right]+k_{1}[\mathrm{ClO}]+k_{8}\left[\mathrm{HO}_{2}\right]\right) /\left(J_{N O 2}+k_{9}[\mathrm{O}]\right)
$$

The uncertainties in the reaction rate coefficients and $J_{\mathrm{NO} 2}$, given by JPL [1987], are shown in Table 3. Assumed values of the uncertainties in the calculated concentrations of $\mathrm{O}, \mathrm{ClO}$, and $\mathrm{HO}_{2}$ are also given in Table 3. The indicated uncertainty in the osone concentration is that associated with the orone measurement. The square root sum of the weighted uncertainty of each term gives an error of $78 \%$ for the $[\mathrm{NO}] /\left[\mathrm{NO}_{2}\right]$ ratio, leading to an error of $25 \%$ in the [NO]/[ $\mathrm{NO}_{\infty}$ ] ratio. $\mathrm{Ma}$ jor species of $\mathrm{NO}_{y}$ other than $\mathrm{NO}_{w}$ are $\mathrm{HNO}_{3}$ and $\mathrm{N}_{2} \mathrm{O}_{5}$, as indicated in Figure 9. Assuming 100\% errors in estimating the concentrations of both species, the $\left[\mathrm{NO}_{0}\right] /\left[\mathrm{NO}_{y}\right]$ ratio at 40 $\mathrm{km}$ at $0600 \mathrm{LT}$ has an uncertainty of $11 \%$, thus leading to an error of $30 \%$ in the estimate for $\mathrm{NO}_{y}$, including the $10 \%$ NO measurement error. Similar estimates at $26 \mathrm{~km}$ and $32.5 \mathrm{~km}$ have given uncertainties in $\mathrm{NO}_{y}$ of $60 \%$ and $45 \%$, respectively.

TABLE 3. Uncertainties in the Reaction Rate Coefficients and the Concentration of the Related Species Calculated for $40 \mathrm{~km}$.

\begin{tabular}{lc}
\hline & Uncertainty \% \\
\hline$J_{N O 2}$ & 30 \\
$k_{3}$ & 40 \\
$k_{4}$ & 20 \\
$k_{14}$ & 30 \\
$k_{18}$ & 20 \\
{$\left[\mathrm{O}_{3}\right]$} & 10 \\
{$[\mathrm{O}]$} & 30 \\
{$[\mathrm{ClO}]$} & 30 \\
{$\left[\mathrm{HO}_{2}\right]$} & 50 \\
\hline
\end{tabular}

The $\mathrm{NO}_{\mathrm{y}}$ values discussed above are summarised in Table 4.

In Figure 10 these calculated $\mathrm{NO}_{y}$ mixing ratios are shown together with our directly measured $\mathrm{NO}_{y}$ concentrations during ascent on June 18, 1988. NO $\mathrm{N}_{y}$ mixing ratios from the Atmospheric Trace Molecule Spectroscopy (ATMOS) instrument [Ruesell et al., 1988] are also shown in Figure 10; the measurements were made on board Spacelab 3 at $30^{\circ} \mathrm{N}$ and $48^{\circ} \mathrm{S}$ in May. The ATMOS instrument determined each major species of the $\mathrm{NO}_{y}$ family by infrared absorption spectra measurements through the limb of the Earth's atmosphere. The $\mathrm{NO}_{y}$ mixing ratio measured by the ATMOS instrument near $40 \mathrm{~km}$ at $30^{\circ} \mathrm{N}$ and $48^{\circ} \mathrm{S}$ in May are listed in Table 5; the average of these values at $39.5 \mathrm{~km}$ is $15.8 \pm 0.9 \mathrm{ppbv}$. This value is in very good agreement with our average $\mathrm{NO}_{y}$ value of 15.5 $\pm 5.0 \mathrm{ppbr}$ for September and June; our June value of 16.5 $\mathrm{ppbv}$ at $44^{\circ} \mathrm{N}$ is especially close to the ATMOS May valne of $16.7 \mathrm{ppbv}$ at $30^{\circ} \mathrm{N}$. The estimated error of the ATMOS data at $39.5 \mathrm{~km}$ is $13 \%$. The egreement of our $\mathrm{NO}_{y}$ values with the ATMOS measurements indicates that the model of Pirre et al. [1989] presents a reasonable description of reactive nitrogen in the upper stratosphere at mid-latitudes.

The ATMOS values of $\mathrm{NO}_{\mathrm{y}}$ agree with our direct measure- 
TABLE 4. Summary of the Derived $\mathrm{NO}_{y}$ and $\mathrm{N}_{2} \mathrm{O}_{5}$ Mixing Ratio, and $\mathrm{NO}_{y}$ /ozone Ratio, and the Measured $\mathrm{O}_{3}$ Mixing Ratio

\begin{tabular}{cccccccc}
\hline Date & $\begin{array}{c}\text { Lat. } \\
{ }^{\circ} \mathrm{N}\end{array}$ & $\begin{array}{c}\text { Temp. } \\
{ }^{\circ} \mathrm{K}\end{array}$ & $\begin{array}{c}\text { Alt. } \\
\mathrm{km}\end{array}$ & $\begin{array}{c}\mathrm{NO}_{y} \\
\mathrm{ppbv}\end{array}$ & $\begin{array}{c}\mathrm{N}_{2} \mathrm{O}_{5} \\
\text { ppbv }\end{array}$ & $\begin{array}{c}\mathrm{O}_{3} \\
\text { ppmv }\end{array}$ & $\begin{array}{c}\mathrm{NO}_{y} / \text { ozone } \\
\times 10^{-3}\end{array}$ \\
\hline Sept. 17,1987 & 44 & 246 & 40.2 & $14.5 \pm 4.3$ & $1.2 \pm 0.4$ & $5.75 \pm 0.3$ & $2.52 \pm 0.76$ \\
June 18, 1988 & 44 & 259 & 39.1 & $16.5 \pm 5.0$ & $1.6 \pm 0.6$ & $5.40 \pm 0.3$ & $3.06 \pm 0.92$ \\
Oct. 4, 1985 & 44 & 227 & 32.5 & $18.5 \pm 8.4$ & $2.2 \pm 1.2$ & $7.0 \pm 0.4$ & $2.64 \pm 1.19$ \\
July 29, 1987 & 32 & 225 & 26.0 & $14.0 \pm 8.5$ & $1.9 \pm 1.2$ & $6.4 \pm 0.3$ & $2.19 \pm 1.34$ \\
\hline
\end{tabular}

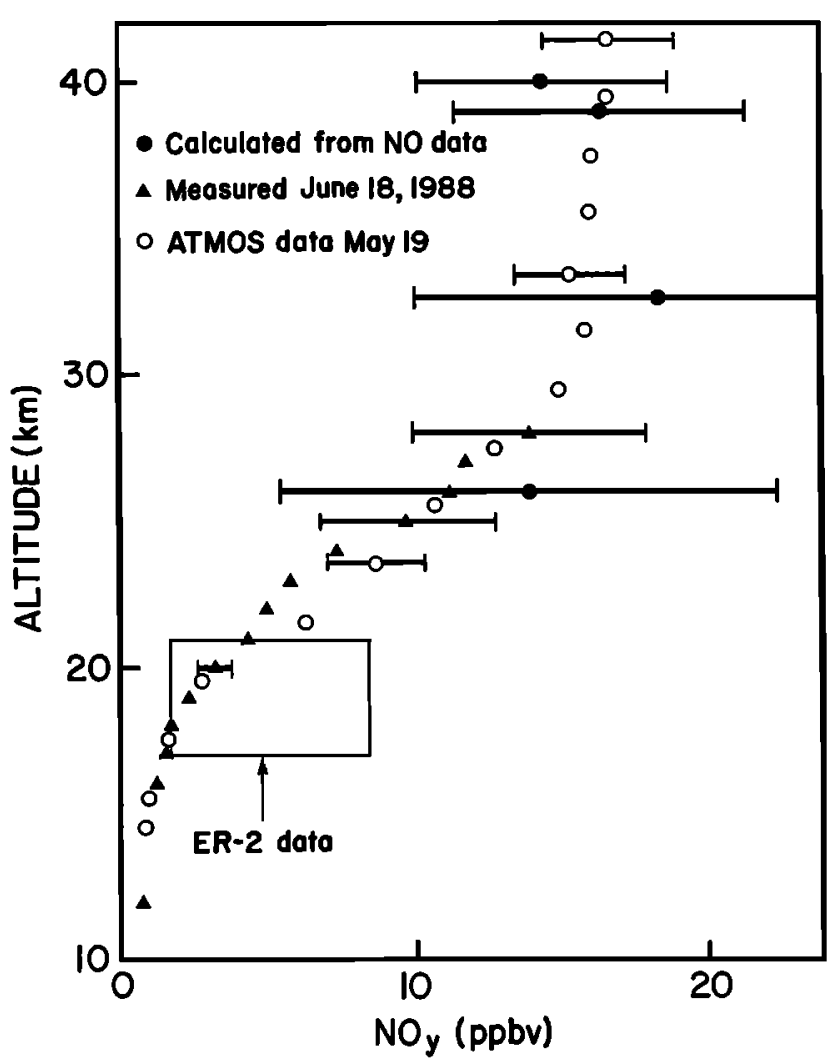

Fig. 10. Comparison of $\mathrm{NO}_{y}$ mixing ratio values from several sources. Solid circles are those obtained from the present NO observations (see Table 1), and the triangles are the direct measurements during ascent on June 18, 1988. Open circles are ATMOS dato at $30^{\circ} \mathrm{N}$ in May [Russell et al., 1988]. The large square labeled "ER 2 Data" indicates the range of volues by $D$. M. Murphy et al. (unpublished manuscript, 1990).

ments at $26 \mathrm{~km}$, but $\mathrm{NO}_{y}$ values estimated from the NO observations (indirect values) at 32.5 and $26 \mathrm{~km}$ are $2-3 \mathrm{ppbv}$ larger. None of these measurements were made simultaneonsly, so the difference of 2-3 ppbv could be due to natural variability caused by dynamical transport.

In general, our direct $\mathrm{NO}_{y}$ measurements agree with those of the ATMOS experiment, as can be seen in Figure 10, although our values are somewhat smaller between 20 and $24 \mathrm{~km}$. In the lower stratosphere, extensive observations of $\mathrm{NO}_{y}$ with a chemiluminescence NO detector combined with a gold cataly tic converter have been made on board the ER 2 aircraft ( $D$. $M$. Murphy et al., unpublished manuscript, 1990). In Figure 10 the range of values obtained at altitudes between 17 and 21 $\mathrm{km}$ and between latitudes $30^{\circ}$ and $45^{\circ} \mathrm{N}$ is indicated as a large

\begin{tabular}{|c|c|c|}
\hline $\begin{array}{c}\text { Altitude } \\
\text { km } \\
\end{array}$ & $\begin{array}{c}\text { Mixing Ratio } \\
30^{\circ} \mathrm{N} \\
\end{array}$ & $\begin{array}{l}\text { ppbr } \\
48^{\circ} \mathrm{S} \\
\end{array}$ \\
\hline 41.5 & $16.7 \pm 2.3$ & $12.9 \pm 1.7$ \\
\hline 39.5 & $16.7 \pm 2.2$ & $14.9 \pm 1.2$ \\
\hline 37.5 & $16.2 \pm 2.1$ & $16.3 \pm 1.8$ \\
\hline
\end{tabular}

From Russell et al., [1988].

square. In the lower stratosphere our values are in the range of the ER 2 data but are somewhat lower than their average value.

NO $y$ and ozone mixing ratios have been found to be correlated quite well in the lower stratosphere (D.M. Murphy et al., unpublished manuscript, 1990). The variability observed in $\mathrm{NO}_{y}$ or ozone alone is greatly reduced when presented as the $\mathrm{NO}_{y}$ /ozone ratio. For this reason the $\mathrm{NO}_{y}$ /ozone ratio can be a more useful, and probably a more meaningful parameter for comparison with other measurements or numerical models. The $\mathrm{NO}_{y} /$ ozone ratios from our simultaneous measurements of NOy and ozone are listed in Table 4 and are shown in Figure 11. As mentioned above, $\mathrm{NO}_{y}$ was measured directly during ascent on June 18,1988 between 12 and $28 \mathrm{~km}$. The observed $\mathrm{NO}_{y} /$ ozone ratio in that altitude region has been presented previously [Kondo et al., 1990]. Smoothed values of the $\mathrm{NO}_{y} /$ ozone ratio for each $1 \mathrm{~km}$ in altitude are shown as triangles in this figure. Above $25 \mathrm{~km}$ the $\mathrm{NO}_{y} /$ orone ratio ranges between 2 and 3 times $10^{-3}$. The $\mathrm{NO}_{y}$ /ozone ratio is observed to increase slightly with altitude from 20 to $40 \mathrm{~km}$.

$\mathrm{N}_{2} \mathrm{O}_{6}$

As can be seen from Figure 9, the calculated $\mathrm{N}_{2} \mathrm{O}_{5}$ concentration at $39 \mathrm{~km}$ at the end of the night on June 18 wes 1.6 ppbv. Similarly, from the model run for September 17 the estimated $\mathrm{N}_{2} \mathrm{O}_{3}$ mixing ratio just prior to sunrise at $40 \mathrm{~km}$ was $1.2 \mathrm{ppbv}$. The estimated uncertainty in the $\mathrm{N}_{2} \mathrm{O}_{5}$ mixing ratio is about \pm 0.5 ppbr associated with uncertainties in osone, $\mathrm{NO}_{y}$ and temperature. The $\mathrm{N}_{2} \mathrm{O}_{5}$ mixing ratio in June at $39 \mathrm{~km}$ derived from the model is $30 \%$ larger than that in September at $40 \mathrm{~km}$. The contribution of the June/September difference in the $\mathrm{NO}_{\mathrm{y}}$ mixing ratio to this $30 \%$ difference in the calculated $\mathrm{N}_{2} \mathrm{O}_{6}$ concentration is about $15 \%$. The difference in stratospheric temperature between June and September of $13^{\circ} \mathrm{K}$ causes a $70 \%$ difference in the value of $k_{5}$ and a $60 \%$ difference in the $k_{5}\left[\mathrm{O}_{3}\right]$ value, when the measured variation of $\left[\mathrm{O}_{3}\right]$ is taken into account. This effect causes the additional $15 \%$ difference in the $\mathrm{N}_{2} \mathrm{O}_{5}$ concentration.

The NO $\mathrm{N}_{\mathrm{y}}$ mixing ratios at 32.5 and $26 \mathrm{~km}$ have been estimated so that the modeled diurnal variations of $\mathrm{NO}$ give the best fit to those observed. The $\mathrm{N}_{2} \mathrm{O}_{5}$ mixing ratios calculated by this model for these $\mathrm{NO}_{\mathrm{y}}$ values are $2.2 \pm 1.2 \mathrm{ppbv}$ and $1.9 \pm 1.2 \mathrm{ppbv}$, respectively. These $\mathrm{N}_{2} \mathrm{O}_{5}$ values are listed in Table 4 and are shown in Figure 12. Measurements of strato- 


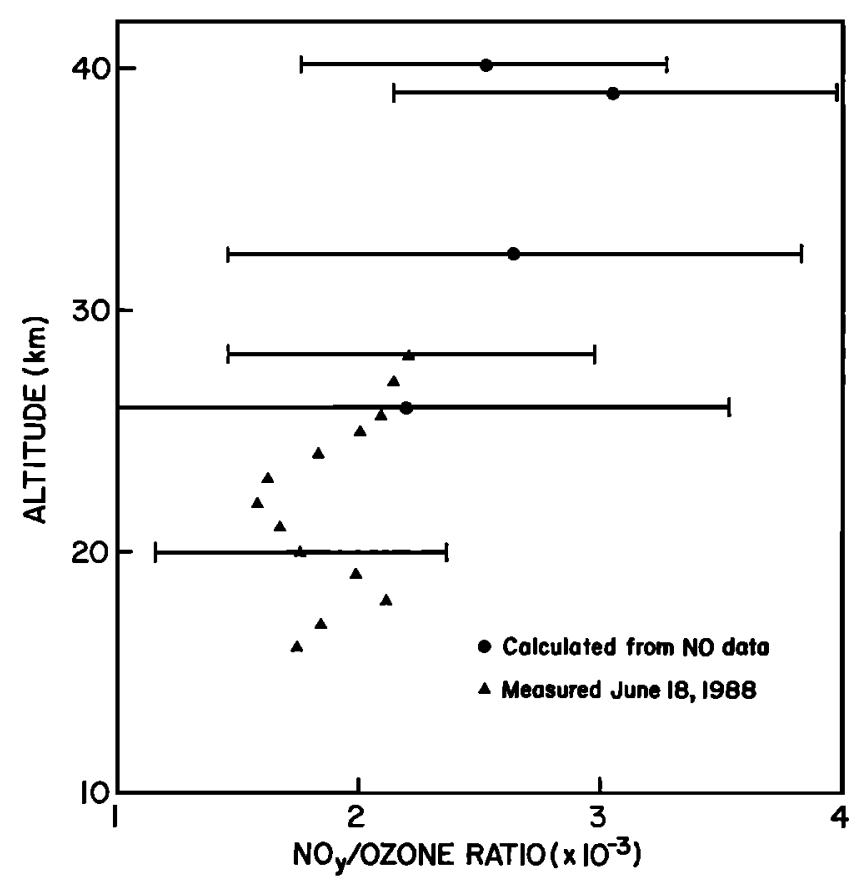

Fig. 11. Profile of the $\mathrm{NO}_{y} /$ ozone ratio. Solid circles are the valnes listed in Table 1 . Triangles are from the measured values of $\mathrm{NO}_{y}$ and ozone during ascent on Jone 18, 1988. See text.

spheric $\mathrm{N}_{2} \mathrm{O}_{3}$ were first made by Roscoe [1982] with a pressuremodulated radiometer and were followed by the measurement of Evans [1986] with a cooled filter spectrometer. Kunde et al. [1988] obtained the predawn $\mathrm{N}_{2} \mathrm{O}_{5}$ mixing ratio from 21 to $39 \mathrm{~km}$ from measurements of the $\mathrm{N}_{2} \mathrm{O}_{3}$ emission spectrum on board a balloon at $32^{\circ} \mathrm{N}$ in September. Their values above $23 \mathrm{~km}$ are also shown in Figure 12, together with the ATMOS $\mathrm{N}_{2} \mathrm{O}_{5}$ data above $25 \mathrm{~km}$ at sunrise at $48^{\circ} \mathrm{S}$ in May. For the ATMOS $\mathrm{N}_{2} \mathrm{O}_{3}$ data the revised values of Rinsland et al. [1989] are shown. The $\mathrm{N}_{2} \mathrm{O}_{5}$ mixing ratio of Kunde et al. [1988] at $39 \mathrm{~km}$ is $1.3 \pm 0.7 \mathrm{ppbv}$, and the ATMOS value at $37.4 \mathrm{~km}$ is $1.32 \pm 0.34 \mathrm{ppbv}$. Those values agree quite well with the present $\mathrm{N}_{2} \mathrm{O}_{5}$ mixing ratio of $1.6 \pm 0.6 \mathrm{ppbv}$ at $39 \mathrm{~km}$ and 1.2 $\pm 0.4 \mathrm{ppbv}$ at $40 \mathrm{~km}$, an average mixing ratio of $1.4 \pm 0.6 \mathrm{ppbv}$. It should be noted that our estimates of $\mathrm{N}_{2} \mathrm{O}_{3}$ in the upper stratosphere have relatively smaller uncertainties than those at altitudes of 26 and $32.5 \mathrm{~km}$, as discussed above. Our value at $32.5 \mathrm{~km}$ is about $0.7 \mathrm{ppbr}$ larger than the valnes of $K$ unde et al. [1988] and the ATMOS data, although the nncertainty in the measurements results in overlap.

From infrared emission measurements, Blatherwick et al. [1989] obtained an $\mathrm{N}_{2} \mathrm{O}_{5}$ concentration of $1.26 \mathrm{ppbv}$ at $30 \mathrm{~km}$ in the early morning on $\mathrm{July} 5$, at $32^{\circ} \mathrm{N}$. However, due to the difference in altitude, direct comparison of this value with our estimate is difficult. At $26 \mathrm{~km}$ our value is again $1 \mathrm{ppbv}$ larger than that of the ATMOS data, but in agreement with the mixing ratio of $2.4 \pm 0.8 \mathrm{ppbv}$ at $28 \mathrm{~km}$ by $K$ unde et al. [1988]. This disagreement can be partly explained by the difference in temperature. The average temperature at $26 \mathrm{~km}$ in May at $48^{\circ} \mathrm{S}$ is usually lower by abont $12^{\circ} \mathrm{K}$ than in $\mathrm{July}$ at $30^{\circ} \mathrm{N}$.

\section{Summary and Conclusions}

The temporal variation of nitric oxide during morning hours at an altitude of about $40 \mathrm{~km}$ was measured at $44^{\circ} \mathrm{N}$ in autumn and summer. The NO mixing ratio was observed to begin a rapid increase when the SZA reached $95^{\circ}$. This injtial rapid increase in NO for SZA between $95^{\circ}$ and $90^{\circ}$ was found to agree quite well with a sero-dimensional photochemical model [Pirre et al., 1989] assuming a constant $\mathrm{NO}_{y}$ mixing ratio. This indicates that behavior of NO near sunrise can be explained by a rapid increase in the photodissociation rate of $\mathrm{NO}_{2}$. The slower increase in $\mathrm{NO}$ that follows in the early morning is also in agreement with the model calculation, although the observed rate of increase is some what larger than that calculated for the September observation. Later in the morning the agreement is better: the observed NO from 0800 LT to local noon in June showed an increase of about 1 ppbv, in excellent agreement with the model. The model indicates that this slow increase is caused mainly by the photodissociation of $\mathrm{N}_{2} \mathrm{O}_{6}$ and a slow increase in the $\mathrm{NO} / \mathrm{NO}_{2}$ ratio. The concentrations of $\mathrm{NO}_{y}$ and $\mathrm{N}_{2} \mathrm{O}_{5}$ in the upper stratosphere have been estimated using the model and measured values of the NO mixing ratio. The $\mathrm{NO}_{y}$ mixing ratio of $15.5 \pm 5.0 \mathrm{ppbv}$ estimated for 39 and $40 \mathrm{~km}$ agrees quite well with the ATMOS measurements [Rinsland et al., 1989]. The $\mathrm{N}_{2} \mathrm{O}_{5}$ mixing ratio derived from the model, $1.4 \pm 0.6 \mathrm{ppbv}$, is also in agreement

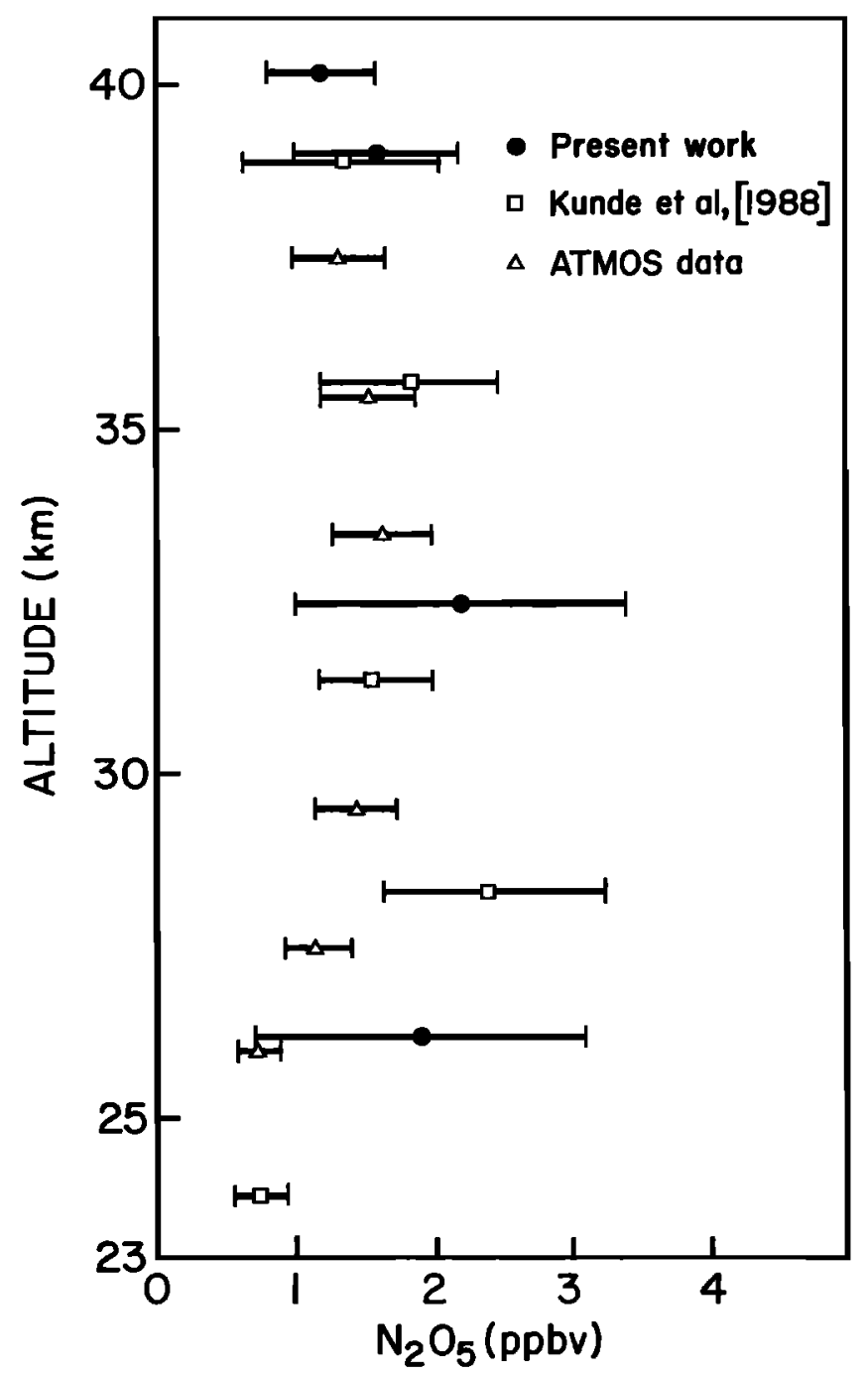

Fig. 12. Comparison of $\mathrm{N}_{2} \mathrm{O}_{5}$ mixing ratios. Solid circles are our estimates given in Table 1. Triangles are the ATMOS measurements [Rinsland et al., 1989], and the squares are the values by Kunde et al. [1988]. 
with the infrared measurements by $K$ unde et al. [1988] and with the ATMOS data [Rinsland et al., 1989].

In conclusion, it can be said that the present measurement of NO is in reasonable agreement with the photochemical model. An observed increase in NO during the early morning hours is somewhat larger than that predicted. However, the differences between the observed and predicted values are within the uncertainties in the measurements of NO, osone, and temperature, and in the reaction rate coefficient of $R 5$. The $\mathrm{NO}_{y}$ and $\mathrm{N}_{2} \mathrm{O}_{5}$ mixing ratios, determined from the model using the present NO measurements, agree well with other recent observations.

Acknowledgments. We wish to thank CNES for its excellent balloon operations and logistic support at Aire sur l'Adour and Gap. The two balloon flights were supported by CNES with participation of Service d'Aéronomie, CNRS. S. Solomon generously provided the computed results of $J_{N O 2}$ used in the present calculation. Thanks are due also to D. M. Murphy and D. W. Fahey, who kindly showed us their paper before publication. We wish to thank N. Toriyama, M. Kanada, H. Jindo, C. Bernard, and J. Gilbert for their technical assistance in the preparation of the balloon-borne experiments. Y. K. acknowledges support by the Ministry of Education, Science and Culture. The work of W. R. S. and J. R. B. was supported in part by NASA Grant NAG9-213 and by the Texas Higher Education Coordinating Board. The calculations were made on the CIRCE at Orsay, France.

\section{Reperences}

Aimedieu, P., Measurement of the vertical ozone distribution by means of an in situ gas phase chemiluminescence ozonometer during the intercomparison ozone campaign, GAP, France, June 1981, Planet. Space Sci., 31, 743-749, 1983.

Aimedieu, P., and J. Barat, Instrument to measure stratospheric ozone with high resolution, Rev. Sci. Instrum., 54, 432-437, 1981.

Aimedieu, P., W. A. Matthews, W. Attmannspacher, R. Hartmannsgruber, J. Cisneros, W. Komhyr, and D. E. Robbins, Comparison of in situ stratospheric ozone measurements obtained during the MAP/GLOBUS 1983 campaign, Planet. Space Sci., 35, 563-585, 1987.

Blatherwick, R. D., D. G. Murcray, F. H. Murcray, F. J. Murcray, A. Goldman, G. A. Vanasse, S. T. Massie, and R. J. Cicerone, Infrared emission measurements of morning stratospheric $\mathrm{N}_{2} \mathrm{O}_{5}$, J. Geophys. Res., 9/, 18337-18340, 1989.

Bollinger, M. J., R. E. Sievers, D. W. Fahey, and F. C. Fehsenfeld, Conversion of nitrogen dioxide, nitric acid, and n-propyl nitrate to nitric oxide by gold-catalyzed reduction with carbon monoxide, Anal. Chem., 55, 1980-1986, 1983.

Evans, W. F. J., Observation of the 8- $\mu \mathrm{m} \mathrm{N}_{2} \mathrm{O}_{5}$ thermal emission feature in the stratosphere, Appl. Opt., 25, 1866-1868, 1986.

Fahey, D. W., C. S. Eubank, G. Hübler, and F. C. Fehsenfeld, Evaluation of a catalytic reduction technique for the measurement of total reactive odd-nitrogen $\mathrm{NO}_{\mathrm{y}}$ in the atmosphere, J. Atmos. Chem., s, 435-468, 1985.

Flsud, J.-M., C. Camy-Peyret, D. Cariolle, J. Laurent, and G. M. Stokes, Daytime variation of atmospheric $\mathrm{NO}_{2}$ from groundbased infrared measurements, Geophys. Res. Lett., 10, 1104$1107,1983$.

Isaksen, I. S. A., and F. Stordal, Ozone perturbations by enhanced levels of CFCs, $\mathrm{N}_{2} \mathrm{O}$, and $\mathrm{CH}_{4}$ : A two-dimensional diabatic circulation study including uncertainty estimates, J. Geophys. Res., $91,5249-5263,1986$.

Jet Propulsion Laboratory, Chemical kinetics and photochemical data for use in stratospheric modeling, Report, Jet Propulsion Lab., Pasedena, Calif., 87-41, 1987.

Kondo, Y., A. Iwata, M. Takagi, and W. A. Matthews, Balloonborne chemiluminescent sonde for the measurement of tropospheric and stratospheric nitric oxide, Rev. Sci. Instrum., 55, 1328-1332, 1984.

Kondo, Y., W. A. Matthews, A. Iwata, and M. Takagi, Measurement of nitric oxide from 7 to $32 \mathrm{~km}$ and its diurnal variation in the stratosphere, J. Geophys. Res., 90, 3813-3819, 1985.

Kondo, Y., W. A. Matthews, P. Aimedieu, and D. E. Robbins, Di- urnal variation of nitric oxide at $32 \mathrm{~km}$ : Measurements and interpretation, J. Geophys. Res., 9s, 2451-2460, 1988.

Kondo, Y., P. Aimedieu, W. A. Matthews, W. R. Sheldon, and J. R. Benbrook, Profiles of nitric oxide in the upper stratosphere, Geophys. Res. Lett., 16, 1379-1382, 1989 a.

Kondo, Y., A. Iwate, M. Pirre, R. Ramaroson, C. Delennoy, W. A. Matthews, M. Koike, and K. Suzuki, Diurnal variation of nitric oxide at $26 \mathrm{~km}$, Geophys. Res. Lett., 16, 867-870, 19896.

Kondo, Y., N. Toriyama, W. A. Matthews, and P. Aimedieu, Calibration of the balloon-borne NO instrument, J. Geomegn. Geoelectr., $41,507-523,1989 c$.

Kondo, Y., P. Aimedieu, W. A. Matthews, W. R. Sheldon, and J. R. Benbrook, A mid-latitude balloon-borne observation of total odd nitrogen, Geophys. Res. Lett., 17, 73-76, 1990.

Kunde, V. G., J. C. Brasunas, W. C. Maguire, J. R. Herman, S. T. Massie, M. M. Abbas, L. W. Herath, and W. A. Shaffer, Measurement of nighttime stratospheric $\mathrm{N}_{2} \mathrm{O}_{5}$ from infrared emission spectra, Geophys. Res. Lett., 15, 1177-1188, 1988.

McElroy, M. B., and R. J. Salawitch, Changing composition of the global stratosphere, Science, 243, 763-770, 1989.

Pirre, M., R. Ramaroson, J. P. Naudet, and P. Rigaud, Altitude distribution of stratospheric $\mathrm{NO}_{3}, 2$, comparison of observation with model, J. Geophys. Res., 94, 6383-6388, 1989.

Ridley, B. A., and H. I. Schiff, Stratospheric odd nitrogen: Nitric oxide measurements at $32^{\circ} \mathrm{N}$ in autumn, J. Geophys. Res., 86, 3167-3172, 1981.

Ridley, B. A., M. McFarlend, J. T. Bruin, H. I. Schiff, and J. C. McConnell, Sunrise measurements of stratospheric nitric oxide, Can. J. Phys., 55, 212-221, 1977.

Rinsland, C. P., G. T. Toon, C. B. Farmer, R. H. Norton, and J. S. Namkung, Stratospheric $\mathrm{N}_{2} \mathrm{O}_{5}$ profiles at sunrise and sunset from further analysis of the ATMOS/ Spacelab 3 solar spectra, J. Geophys. Res., 94, 18341-18349, 1989.

Robbins, D. E., Balloon in situ measurements of ozone with the NASA-JSC UV photometer, in Atmospheric Ozone, Proceedings of the Quadrennial Ozone Symposium, Halkidiki, Greece, edited by C. S. Zerofos and A. Ghazi, D. Reidel, Hingham, Mass., 460464, 1985.

Robbins, D., et al., Ozone measurements from the balloon intercomparison campaign, J. Atmos. Chem., 10, 181-218, 1990.

Roscoe, H. K., Tentative observations of stratospheric $\mathrm{N}_{2} \mathrm{O}_{5}$, Geophys. Res. Lett., 9, 901-902, 1982.

Roscoe, H. K., B. J. Kerridge, L. J. Gray, R. J. Wells, and J. A. Pyle, Simultaneous measurements of stratospheric NO and $\mathrm{NO}_{2}$ and their comparison with model predictions, J. Geophys. Res., 91, 5404-5419, 1986.

Russell, J. M., III, C. B. Farmer, C. P. Rinsland, R. Zander, L. Froidevaux, G. C. Toon, B. Gao, J. Shaw, and M. Gunson, Measurements of odd nitrogen compounds in the stratosphere by the ATMOS experiment on Spacelab 3, J. Geophys. Res., 93, 17181736, 1988.

Shimazaki, T., The photochemical time constants of minor constituents and their families in the middle atmosphere, J. Atmos. Terr. Phys., 46, 173-191, 1984.

Solomon, S., R. W. Sanders, M. A. Carroll, and A. L. Schmeltekopf, Visible and near-ultraviolet spectroscopy at McMurdo station, Antarctica, 5, Observation of the diurnal variations of $\mathrm{BrO}$ and OClO, J. Geophys. Res., 94, 11393-11403, 1989.

P. Aimedieu, Service d'Aéronomie, Centre National de la Recherche Scientifique, P. O. Box 3, 91371 Verrières-le-Buisson, CEDEX, France.

J. R. Benbrook and W. R. Sheldon, Department of Physics, University of Houston, Houston, TX 77204-5504.

A. Iwata and Y. Kondo, Solar-Terrestrial Environment Laboratory, Nagoye University, 3-13 Honohara, Toyokawa, 442, Japan.

W. A. Matthews, Department of Scientific and Industrial Research, Physical Sciences, Lauder 9182, Central Otago, New Zealand.

M. Pirre and T. C. Ramaroson, Laboratoire de Physique et Chimie de l'Environnement, Centre National de la Recherche Scientifique, 45071, Orléans, France.

(Received April 23, 1990; revised August 20, 1990; accepted September 6, 1990.) 